\title{
DIVISION OF FAMILY PROPERTY IN TAIWAN
}

\begin{abstract}
Since property ownership affords the elderly some control over resources and perhaps even support and respect from potential caretakers, examination of the decision to transfer property to children can help us gain insight into the underlying dynamics of intergenerational exchanges between the elderly and their children. In this paper we use data from the 1989 Survey of Health and Living Status of the Elderly in Taiwan to explore the demographic and social characteristics associated with pre-mortem property division. From both bivariate and multivariate analyses, we find that the likelihood of property division is positively related to age, widowhood, natality in Taiwan, rural residence, and the number of living children, and negatively related to education. After controlling for other characteristics, our results show that widows are more than twice as likely as widowers to have divided all their property. These results lend statistical support to findings in the ethnographic literature on the Chinese family.
\end{abstract}

Key Words: old age security, resource control, property transfer, inheritance, Chinese culture, Asia

Having reached the end of its demographic transition, Taiwan now faces social and economic challenges posed by an aging population. As in many Asian countries, care for the elderly has traditionally been borne by the family. For example, the World Health Organization study in Fiji, Malaysia, the Philippines and the Republic of Korea found that between 70 and 80 percent of older people aged 60 and over lived with their children (Andrews, Esterman, BraunackMayer and Rungie 1986). Co-residence is usually taken as an indicator of family relations. With respect to Taiwan, the 1989 Survey of Health and Living Status of the Elderly has found that about 75 percent of ever-married persons aged $60+$ with at least one living child currently live with a child (Casterline, Williams, Hermalin, Chang, Chayovan, Cheung, Domingo, Knodel and Ofstedal 1991). Although traditional living arrangements remain the norm, their prevalence has declined over time. The decline in part reflects the parents' desire for privacy and independent living (Moore 1990; Sun 1991; Chang and Ofstedal 1991). However, many researchers believe that in the whole Asia and Pacific region, traditional filial piety has been weakening or will inevitably weaken (e.g. Freedman 1986; Martin 1988). Although the family will likely continue to act as the main source of elderly support in Taiwan in the near term, government policies reflect a deepening concern over an erosion of eldercare provided by the family (Moore 1990). ${ }^{1}$

Study of pre-mortem transfers of property control from the elderly to their children merits further research because it can help us better understand family dynamics and old age security. Economists have concentrated on intergenerational transfers in bequests and particularly on the motivation of benefactors ( $c f$. Becker and Tomes 1979; Becker 1991; Bernheim, Shleifer and Summers 1985). Several economic models of transfer behavior can be helpful for thinking about pre-mortem property division by parents. For example, the "altruism" model 
hypothesizes that parents' "utility is raised when their children are better off" (Becker 1991:5), whereas the more strategic motive of "self-interested exchange" assumes that parents' actions anticipate the behavior of their children. The decision to divide property is generally prefaced by careful consideration and perhaps some awkward negotiation. Parents may want to retain control of their assets if such control guarantees their economic well-being at older ages or the receipt of care from children. Simmons (1945: 46) has argued that even in primitive societies, property rights "have played a significant role in providing security for individuals facing old age." In a broader sense, the attitudes of the elderly towards property division, as with inheritance, can serve as an indicator of intergenerational relations ( $c f$. Tsuya and Martin 1992). If property division diminishes old age security, knowledge of characteristics associated with high risk of property division would benefit formulation of government policies. The objective of this paper, therefore, is not to test a particular economic framework but rather to examine in a systematic way differentials in property division by selected demographic and social characteristics of an older population.

Perhaps because reasonably good data on wealth or property transfers between living parties are rarely available, empirical research on the determinants of property transfers (or non-transfers) has been limited. With respect to Chinese societies, Ho (1967: 163) has remarked that "detailed descriptions of the division of family property are rather scarce because Neo-Confucian and more ancient teachings did not favor the keeping of such accounts." Since Ho's writing, a number of ethnographic studies have appeared that offer some insight into the process of property partition and inheritance among Chinese families (cf. Wolf 1968; Pasternak 1972; Ahern 1973; Cohen 1976; Cohen 1978; Freedman 1979; Sung 1981; Pasternak 1983; Greenhalgh 1985; Watson 1985). ${ }^{2}$ Although of enormous interest, it is difficult to generalize from the extant literature about the characteristics of persons who have experienced the division of property. Multivariate analyses of the factors associated with property division are even scarcer. Data from the 1989 Survey of Health and Living Status of the Elderly in Taiwan on property ownership and property division, including information on how long ago property was divided, enable us for the first time to offer some generalizations that can serve to broaden our understanding of the underlying dynamics of pre-mortem intergenerational exchanges by the Chinese on the island of Taiwan. Based on a random sample of 4,049 respondents representative of the elderly population in Taiwan, this survey provides unusually detailed information about the individual characteristics of the elderly, their children, and their main sources of support.

These data from Taiwan lend credence to the claim that property ownership gives the elderly some control over their resources, and perhaps even the amount of support and respect they receive from potential caretakers. More than 68 percent of those surveyed responded "yes" to the question, "Do you think it's important for old people nowadays to keep some property to make sure their family treats them with respect?" This suggests that many may feel that adequate support and care will continue so long as they control a sizable portion 
of "family" wealth. Responses to this question were independent of the respondent's place of birth, sex, age, marital status, education, number of living children, total monthly income, and even whether property has been completely, partially, or not yet divided among children. However, respondents who received less frequent care if ill in the last year were more likely to affirm the importance of property ownership for respect, as were those who felt less loved by their children. Given that division of family property does occur, it is safe to say that either the economic security gained from control of family property is greatly exaggerated, or that other considerations persuasively argue against keeping property intact. Before we present the empirical analysis of the factors in pre-mortem property division, we briefly discuss the cultural context of property division in Chinese society since cultural expectations concerning property transfers and bequests may shape decision-making behaviors of both parents and children.

\section{TRADITIONAL AND CONTEMPORARY CONCEPTS OF PROPERTY DIVISION}

According to custom, property was usually divided among sons, the largest portion sometimes going to the eldest son ( $c f$. Freedman 1979; Wolf and Huang 1980). ${ }^{3}$ Chen (1985: 124) has observed that women inherited property "only in rare and exceptional cases, for instance when there was no son in the family or when the family failed to adopt one before the death of the male head of the household." In his research on family property in traditional China, Shiga (1978: 135) has documented the practice since ancient times of leaving a portion of the property (usually a fixed piece of land) for parents, "under the title yang lao (for support of old age) or yang shan (support and care)."

Taiwan's Law of Succession stipulates that other than the spouse, first order rights of inheritance to property go to blood-lineal descendants, followed by (in order) parents, brothers and sisters, and grandparents. As stipulated by law, any inheritance is to be equally divided among the spouse and first order heirs. ${ }^{4}$ Although not popular among the Chinese, a will supersedes laws of succession. Should a will exclude a lawful heir, recourse can be sought through Title VI of the Law of Succession which stipulates compulsory portions. The compulsory portion for a child, parent, or spouse is one-half that which each would have inherited absent a will. Although contemporary inheritance laws include daughters as equal beneficiaries, there is evidence that women have been pressured to waive their rights to inheritance (Cohen 1978; Tang 1985). Chen (1985) has even suggested that one way for parents (usually the father) to circumvent equal inheritance to children of both sexes is to transfer all the family estate to the sons so that there would be no inheritance at the time of the father's death. Backed by both tradition and law, a son's expectation that he will inherit at least some of the family property is thus justifiable, whereas a daughter's is less certain.

Schurmann (1956: 512) has noted that in traditional Chinese society, "there was no legal or customary force demanding division upon [the ancestor's] death. 
Division was inherently the result of dissension within the family and pressure from without, in particular the fiscal pressure of the state. The predominance of division among the peasant masses reflects both of these pressures." The marriage of a son or division of the family can also trigger the act of property division. ${ }^{5}$ In Taiwan today, other external forces may pressure the division of property prior to the death of the patriarch or matriarch. According to legal experts, the "high inheritance tax not only motivates children to obtain title to properties prior to their parents' demise but also prompts parents to transfer properties [during their lifetime] to their children ... by all possible means. As a solution to this, voices have recently been heard in the Legislative Yuan for the lowering of inheritance tax rates so as to encourage payment of the tax" (Chun $\mathrm{Li}$, personal communication April 1992). ${ }^{6}$ If one assumes that parents take their children's welfare into account, timely avoidance of the inheritance tax may serve as a catalyst in the decision to transfer property, especially as the parent gets on in years. ${ }^{7}$

Whatever economic reasons there are to divide the property, the actual transfer will likely depend on the importance placed on property ownership as a means for controlling both economic and caregiving resources. The existence of formal contracts that stipulate the exchange of care for property ( $c f$. Cohen 1978) makes explicit the concerns of the benefactor. Anecdotal evidence from West Town, China, for example, suggests that aged fathers "do not necessarily enjoy much authority over their male children once the latter are married and have taken a portion of the family property" (Hsu 1967: 131). Recall also that regardless of demographic or socioeconomic characteristics, more than 68 percent of the elderly surveyed in Taiwan consider property ownership to be important for ensuring respectful treatment by family members. If property ownership indeed contributes critically to old age security, it is important to identify those elderly with greater likelihood of property division. As we shall see, property division does not occur uniformly across demographic and social groups.

\section{DATA AND METHODS}

Data for this study come from the 1989 Survey of Health and Living Status of the Elderly in Taiwan, which are based on a national probability sample of the entire elderly population aged 60 and over. Details of the sampling plan and questionnaire are available elsewhere (Taiwan Provincial Institute of Family Planning, Population Studies Center and Institute of Gerontology, University of Michigan 1989). Self-reported responses to the question on property division ("Have you (and your spouse) divided part or all properties among your children?") fall into four categories: 1) all divided; 2) part divided; 3) none divided; and 4) no property. Various interpretations of the term "property" were suggested by the survey responses. It was evident that respondents may not categorize the house which they own and in which they currently reside as divisible property. For example, of the 2,047 noninstitutionalized (otherwise 
nonrestricted) respondents who reported self or spouse as the owner of current residence, 5 percent claimed to have divided all property and 15 percent claimed to have no property. One explanation for the apparent inconsistency may be that the respondent actually has no property and the spouse has sole ownership of the house. Shared ownership of property between a husband and wife also presents some ambiguity. In the case where property was divided among the wife and children at the time of the patriarch's death, it is unclear whether a widow would respond that her and her deceased husband's property has been divided totally or partially. It is conceivable that the widow could respond that her property (i.e. the portion she has owned solely since her husband's death) has not yet been divided. An example of the importance of the distinction between family property and personal property arises in reference to the wife's dowry. Shiga (1978: 118) has observed that the wife's dowry "remains the property of the couple" and "is never pooled with the household property belonging to a larger group that includes the husband's parents and brothers. This was a cardinal rule, unchanged throughout the ages." Indeed, for those in rural Taiwan today, Chen (1985: 117) reports that "the major portion of a dowry is considered as property given to the bride for her own use and control." Finally, it is unclear whether substantial gifts of assets to children (e.g., dowries, money to start a business) are perceived by the respondents to be transfers of property. Although clarification of the distinctions between personal and family property, and the nature of the assets constituting divisible property, must await future follow-up surveys, we are convinced that the quality of the 1989 survey data remains high and that analysis using these data enable us to begin to generalize for the first time about the characteristics of the elderly who are prone to property division.

Of the noninstitutionalized respondents with at least one living child, 15.5 percent claimed to have divided all property; 10.1 percent have divided part; 45.3 percent have not divided any; and 29.1 percent reportedly had no property. Whether or not a respondent has divided his or her property, or whether the respondent had any property to begin with, does not appear to affect perceptions about the importance of keeping property to ensure respect from family members (Table I). Table I also reveals that regardless of the importance placed on property ownership for respect, consistently about 15 percent have divided all their property and about 45 percent have not yet divided any of their property. The Pearson chi-square statistic under the null hypothesis of independence between perceived importance of keeping property and actual division of property is 5.7 for 6 degrees of freedom. The apparent independence between attitude and behavior may mask the underlying dynamics of decision-making at work. A respondent's attitude about the importance of property ownership may influence the decision to (or not to) transfer property, while the events occurring subsequent to property division can help shape current attitude about the importance of property ownership. Thus, just as property division can alter total monthly income, property may be kept intact precisely because division would lower income. The confounding of attitude and behavior, or action and outcome, makes it difficult to determine the direction of causality, especially since we are 


\section{TABLE I}

Perceived importance of keeping property and actual division of property

\begin{tabular}{llllr}
\hline & \multicolumn{2}{l}{$\begin{array}{l}\text { "Do you think it's important for old people nowadays to } \\
\text { keep some property to make sure their family treats them } \\
\text { with respect?" }\end{array}$} \\
\cline { 2 - 5 } "Have you divided part & No & Depends & Yes & Total \\
$\begin{array}{llllr}\text { or all properties among } \\
\text { your children?" }\end{array}$ & No & & & 566 \\
\hline All & 159 & 13 & 394 & 100.0 \\
Part & 28.1 & 2.3 & 69.6 & 368 \\
& 124 & 8 & 236 & 100.0 \\
None & 33.7 & 2.2 & 64.1 & 1,668 \\
& 477 & 38 & 1,153 & 100.0 \\
No property & 28.6 & 2.3 & 69.1 & 1,167 \\
& 345 & 34 & 788 & 100.0 \\
Total & 29.6 & 2.9 & 67.5 & 3,769 \\
& 1,105 & 93 & 2,571 & 100.0 \\
\hline
\end{tabular}

Notes: Row percentages shown in italics. Pearson $x^{2}=5.7,6$ d.f. Missing observations: 241.

Source: 1989 Survey of Health and Living Status of the Elderly in Taiwan (noninstitutionalized population only).

currently limited to data from only one cross-section. We have therefore chosen to incorporate in the analysis only the relatively fixed characteristics of the respondent, with particular attention given to demographic variables.

For the empirical analysis, we are interested in identifying the characteristics of the respondents who have divided their property. The remainder of our analysis is restricted to those individuals for whom property division is a realistic choice, i.e. those respondents who have property to divide (about 70 percent of the total sample) and who have at least one living child (94.6 percent of the total sample). We also exclude from our analysis the elderly living in institutions (less than 1 percent of the sample), most of whom have no property. Explanatory variables are of two types: demographic (age, sex, marital status, number of living children, number of living sons); and social (education, place of birth, type of residence). All independent variables are categorical and are represented by blocks of dichotomous indicators in regression analysis. Ethnicity was excluded from the analysis because an earlier analysis $(\mathrm{Li}$ and $\mathrm{Lin}$ 1992) revealed that the only interesting differentials by ethnicity are the contrast between Mainlanders and Taiwan natives, which is captured by the place of birth variable. We begin first by examining the patterns in property division outcome by the selected demographic and socal characteristics individually. 
Since there is a natural order to our dependent variable, property division outcome, ordered probit analysis (McKelvey and Zavoina 1975) is employed to model the factors associated with the likelihood of total or partial property division in both the bivariate and multivariate analyses. In the ordered probit model, we assume that there is a continuously distributed latent variable $y^{*}$ that gives rise to the observed ordinal variable $y$ ( $y=0$ if none divided, 1 if part divided, and 2 if all divided). We treat $y$ as a discrete realization of $y^{*}$ through the following threshold measurement model (e.g., Xie 1989: 336):

$$
\begin{aligned}
& y=2 \text { if } \mu \leq y^{*} \\
& y=1 \text { if } 0 \leq y^{*}<\mu \\
& y=0 \text { if } y^{*}<0,
\end{aligned}
$$

where $\mu$ is the threshold (to be estimated) separating $y=2$ and $y=1$, and 0 is the normalized threshold separating $y=1$ and $y=0$. We next regress $y^{*}$ linearly on independent variables (x). That is, for the $i$ th person,

$$
\mathrm{y}_{i}^{*}=\underline{\beta}^{\prime} \underline{x}^{i}+\varepsilon^{i}
$$

where $\underline{\beta}$ is the parameter vector. After we assume the independence of $\varepsilon^{i}$ across observations and the standard normal distribution for $\varepsilon^{i}$, the model is estimable via the maximum likelihood method. Note the following relationship between probabilities and model parameters:

$$
\begin{aligned}
& \operatorname{Prob}\left(y^{i}=2\right)=1-\Phi\left(\mu-\beta^{\prime} x^{i}\right) \\
& \operatorname{Prob}\left(y^{i}=1\right)=\Phi\left(\mu-\underline{\beta}^{\prime} x^{i}\right)-\Phi\left(0-\underline{\beta}^{\prime} x^{i}\right) \\
& \operatorname{Prob}\left(y^{i}=0\right)=\Phi\left(0-\underline{\beta^{\prime}} x^{i}\right),
\end{aligned}
$$

where $\Phi($.$) is the cumulative distribution function of the standard normal.$

\section{FINDINGS}

\section{Bivariate Analyses}

Patterns in property division by individual explanatory variables are shown in Table II. The first three columns in Table $\Pi$ are row percentages. A separate ordered probit model was run for each block of explanatory variables so that comparisons could be made with the multivariate model to be presented later. For each model, the first coefficient for the reference category is the intercept (indicated by an asterisk) and the other coefficients indicate the effects of the independent variables on the latent tendency to have divided property. Because all the independent variables are dummy variables, the effects here always represent contrasts with the reference category. The statistical significance testing for global differences is assessed using the $\log$-likelihood $\chi^{2}$-statistic with the number of degrees of freedom equal to the number of $\underline{\beta}$ parameters, except for the intercept, in the model (reported in the last two columns for each block of independent variables). A unique threshold parameter $(\mu)$ is estimated and reported for each model in Table II. 


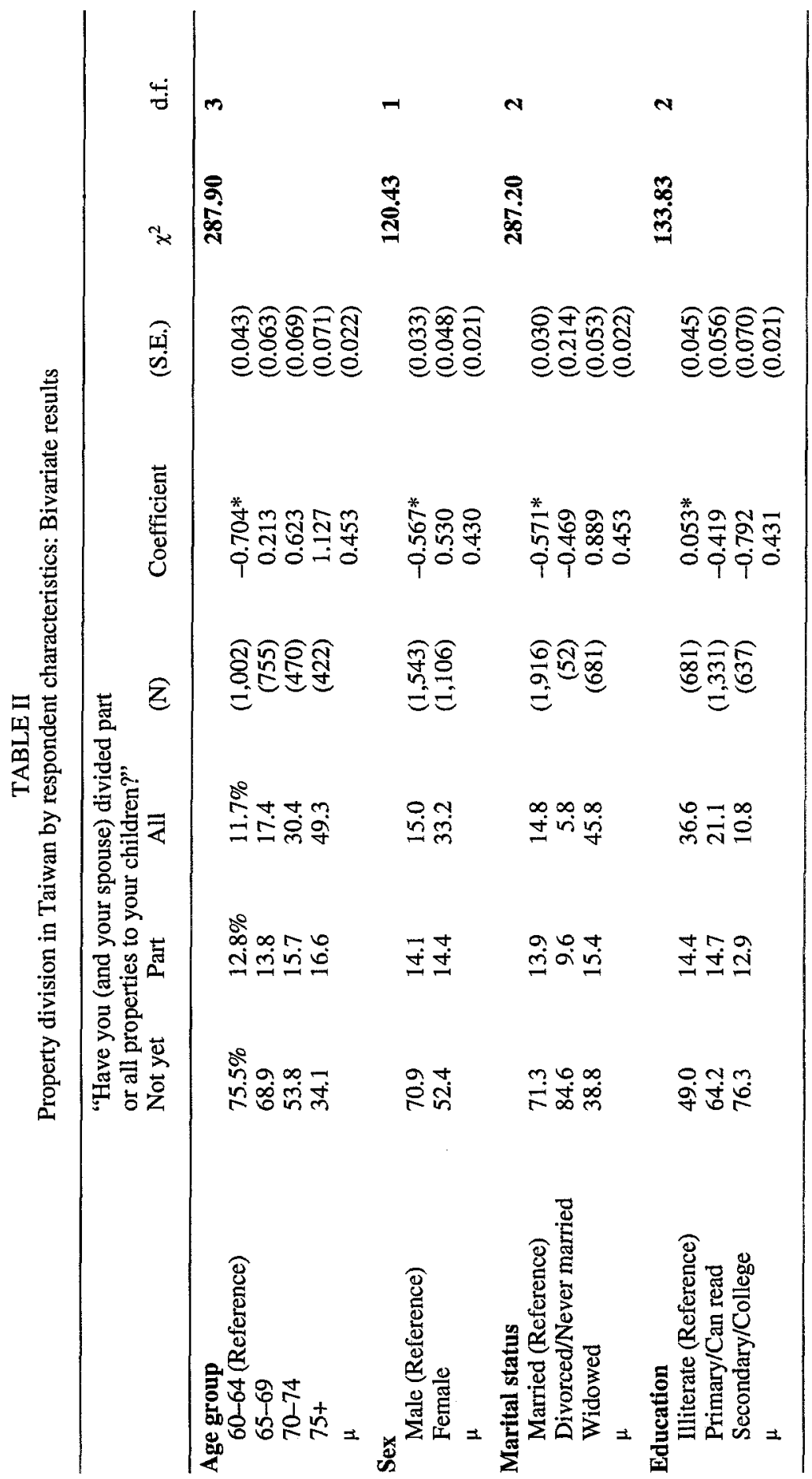


FAMILY PROPERTY IN TAIWAN

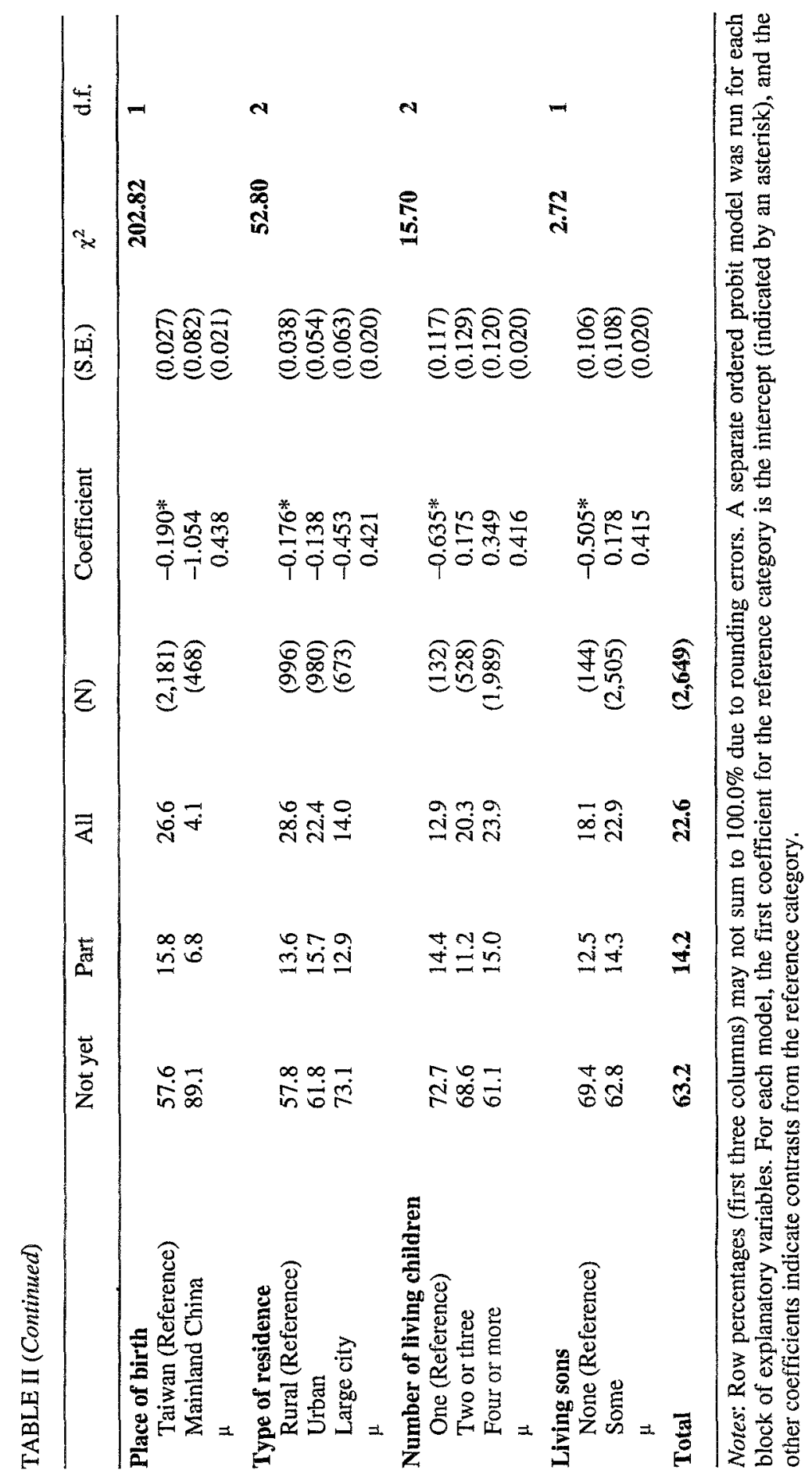


With each successive age group, it is apparent that the proportion of respondents who have divided all property among their children increases (from 11.7 to 49.3 percent) and the proportion who have not yet divided their property steadily decreases (from 75.5 to 34.1 percent). This pattern gives rise to two plausible interpretations: 1) the likelihood of property division increases with age, particularly with the increased risk of losing a spouse; 2) cohort differences reflect changes in attitudes of the elderly through time. The "younger-old" may be more determined to maintain ownership of their property, particularly if concern about old-age security has intensified over time as a result of declining fertility and the perceived weakening of traditional values.

Although there is virtually no difference between male and female respondents as to the proportion who have divided part of their property to their children, the differential in percentages by sex among those who have divided all their property (15.0 percent of male versus 33.2 percent of female respondents) and those who have not yet divided any of their property ( 70.9 percent of male versus 52.4 percent of female respondents) is quite striking. If women feel (or are socialized into thinking) they are less capable of managing property, they may be more inclined to delegate such duties to their children. We speculate that women may be more likely to consider an exchange of property for care (e.g. Gallin 1986). Part of the differential in property division by sex may also be attributed to the tradition that property is divided at the time of the patriarch's death.

As anticipated, property division was much more often associated with widowed respondents. It is reasonable that the death of a spouse often prompts the division of family property. Only 38.8 percent of widowed respondents have not yet divided any of their property, compared with 71.3 percent of currently married respondents. We expect that if property is divided generally at the time of death, the effect of widowhood still should be strong even after controlling for age. We also suspect that there will be a stronger effect of widowhood if the respondent is female.

Not surprisingly, male respondents tended to have more education than their female counterparts. About 65 percent of female respondents were illiterate compared to about 21 percent of male respondents. Education was reported for both the respondent and the spouse in number of years of schooling completed. Since it is likely that the decision to divide property is influenced to a greater extent by the educational level of the husband rather than of the wife, we chose to use own education if the respondent is male and spouse's education if the respondent is female. If spouse's education was not applicable or not stated for a female respondent, own education served as a proxy. ${ }^{8}$ Education was specified as a categorical variable with three levels: illiterate; primary/can read (1-6 years); and junior high or junior vocational or higher (7-17 years). Classification of property division by educational level shows the prevalence of property division to decrease with education. It is possible that the more educated may be better able to manage their properties than the less educated. Because younger respondents tend to be more educated, part of the differences by education may 
also reflect cohort effects represented by age.

Large differences in property division behavior were observed by place of birth (Taiwan or Mainland China). Whereas more than half of the Taiwanese have not yet divided their property, almost 90 percent of the Mainlanders have yet to divide their property. These findings may be explained partly by the composition of the Mainlanders (see Hermalin, Ofstedal and Chi 1992 for further details on the dramatic differences in demographic composition between Taiwanese and Mainlander elderly). Only 16 percent of the Mainlanders in our sample (i.e. noninstitutionalized persons with at least one living child and property to divide) are female compared to the Taiwanese respondents, of whom 47 percent are female. Relative to the native Taiwanese, Mainlanders are younger, report higher levels of education, more often live in urban areas, are less often widowed, and generally have fewer children. Many of these factors may help to explain the persistence of Mainlanders in avoiding property division. Property division was also more common among rural residents, less common in urban areas, and even less likely in large cities. Residential differences in property division may reflect the differences in land holdings; land is easier to carve up and use in rural areas whereas land is scarcer in urban areas.

We have already controlled for the availability of children by selecting for our analysis only those respondents who have at least one living child. Of the 2,666 respondents in our working sample, 2,000 have four or more living children. The less frequent occurrence of property division for those respondents with only one living child compared to those with more living children may reflect the irrelevance of property division considerations if there is a sole heir. Although we would conclude from the $\chi^{2}$-statistic that property division outcomes are affected by the number of living children $\left(\chi^{2}=15.7,2\right.$ d.f.), it is interesting to note that the effect of having a living son is not statistically significant $\left(\chi^{2}=2.72,1\right.$ d.f. $)$.

\section{Multivariate Analysis}

The preceding bivariate results can be seen as the "total effects" of the explanatory variables on the outcome of property division, clearly different from the "net effects" controlling for the presence of other explanatory variables. For example, we would like to know whether there is a net difference between women and men after we control for the fact that men generally have more education than women. Similarly, we would like to test whether Mainlanders are indeed less likely to divide than Taiwanese after we control for the compositional differences in age, education, sex, residence, and number of children between the two groups. In our multivariate analysis, we achieve statistical controls by simultaneously including various additive effects and interaction effects in a single ordered probit model. In Table III, we report three such models. All independent variables are categorical and are represented by blocks of dichotomous indicators in the regressions. Since property division appeared to be independent of the availability of living sons in the bivariate analysis, the 


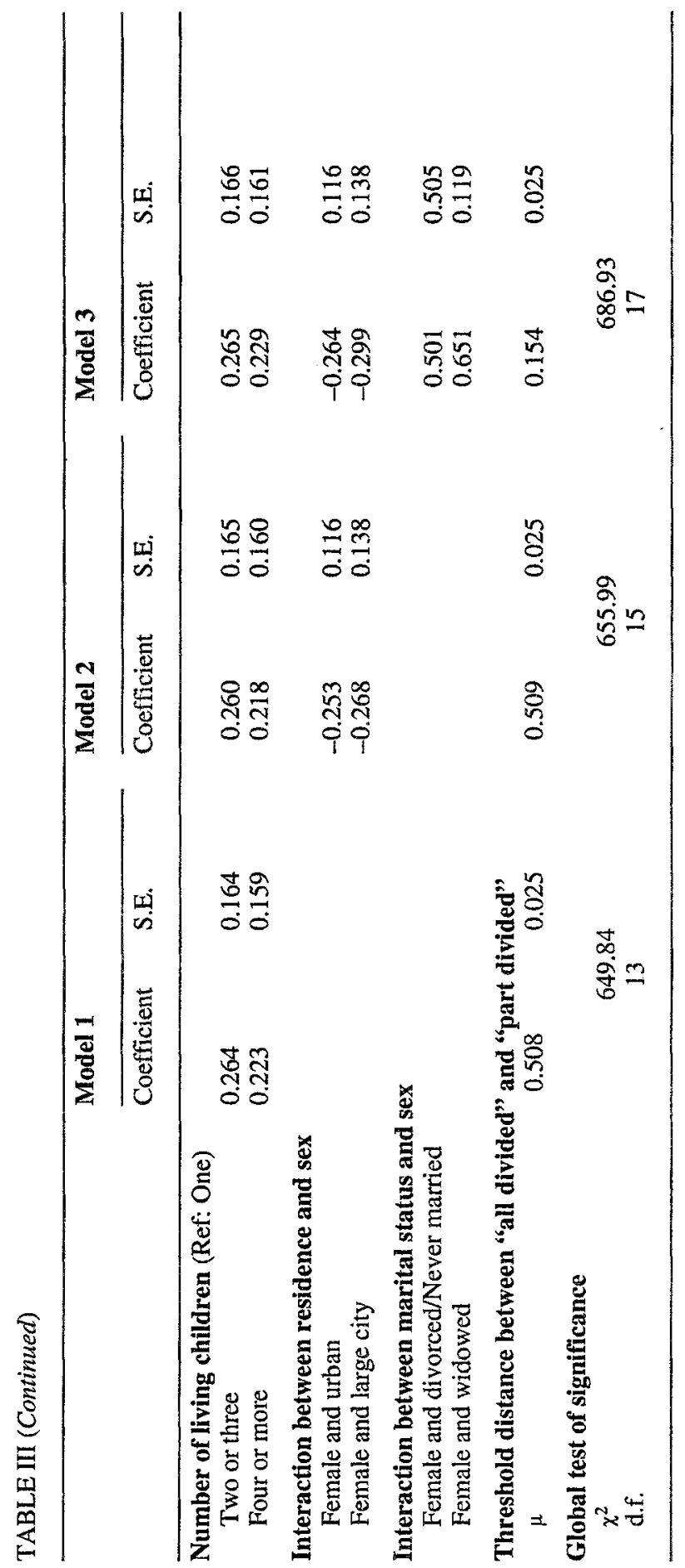


number of living children was selected as the more appropriate offspring variable.

The ordered probit coefficients and standard errors based on Model 1 with only additive effects are shown in the first two columns of Table III. The coefficients show the effect of a particular demographic or social characteristic on the likelihood of property division. Overall, the estimated effects of the explanatory variables in Model 1 are much smaller, albeit in the same directions, than those singularly estimated from the bivariate models reported in Table II. The tendency for property division remains higher if the respondent belongs to an older age group, is female, widowed, or has more children. The tendency towards property division is lower if the respondent is (or has a spouse who is) more educated, was born in the Mainland (as opposed to in Taiwan), or currently resides in urban areas (particularly in large cities). These findings demonstrate that the earlier bivariate results are still valid qualitatively within the multivariate context, even though a large part of the bivariate effects is due to confounding by other variables.

Including an interaction effect between sex and type of residence in Model 2 provided significantly greater explanatory power $\left(\chi^{2}=6.15,2\right.$ d.f. $)$. The estimated coefficients suggest that although female respondents are overall more likely to have divided property, the male-female difference is significantly smaller in urban areas or large cities than in rural areas. Alternatively, they suggest that the effects of residence are significant for the most part only for women.

If the death of a patriarch would more likely prompt the division of property, we expect the probability of property division to be higher for persons who are female and widowed, i.e. there should be a strong interaction effect between property division and being a widowed female. Indeed, the inclusion of the interactions between sex and marital status in Model 3 improves the explanatory power of Model $2\left(\chi^{2}=30.94,2\right.$ d.f.). The coefficient for the interaction between female and widowhood is estimated to be large (0.651) with a small standard error (0.119), meaning that females' higher risk of property division is further raised if they have lost their husband, or alternatively, the effect of widowhood is larger for females than for males.

To interpret the interaction coefficients in terms of probabilities rather than in latent probits, we plot the predicted probabilities by sex and place of residence (Figure 1) and by sex and marital status (Figure 2). It is evident that the residence effects are much larger for women than for men. Women in large cities had a higher predicted probability for total property division than men in large cities (18.3 percent versus 12.2 percent), but the contrast between the sexes is much greater in rural areas (32.1 percent versus 15.4 percent). This suggests that women in rural areas are less likely than urban women to break with tradition and share equal power with male family members. Another explanation could be that women in large cities may be better able to counter pressures to divide their property.

Estimated probabilities of property division (i.e., prob(All), prob(Part), 


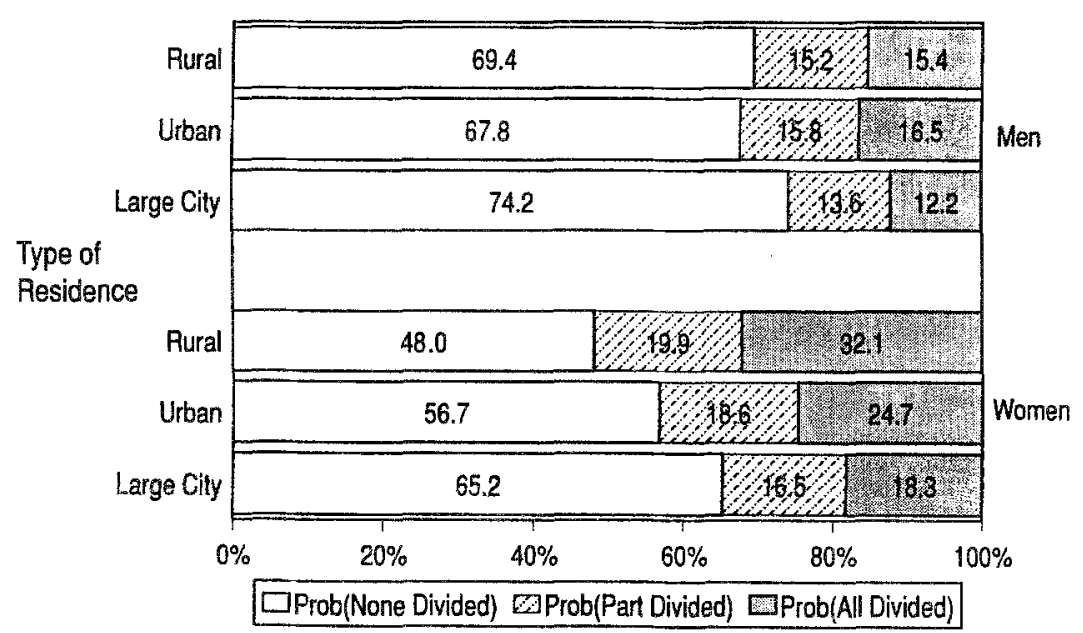

Note: Predicted probabilities are based on Model 3

Fig. 1. Predicted probabilities of property division by type of residence and sex Note: Predicted probabilities are based on Model 3

prob(None)) differ slightly by sex in comparisons based on the married population: 71.7 percent of married men have not divided their property compared to 69.6 percent of married women. The probability of dividing all property is higher for both widowed males and widowed females when compared to the probabilities for males and females who are not widowed (Figure 2). Widowed females are substantially more likely to divide all their property than are widowed males. Where 19.5 percent of widowed men would be expected to have all their property divided, the analogous probability for widowed women is 44.2 percent. Women are thus more than twice as likely to have divided all property in their widowhood than older men.

Since the 1989 survey also queried respondents about when property was divided, we find some support for the notion that for those who are widowed and have divided property, the division coincides with the time of the spouse's death, particularly if the respondent is female. For 36 percent of widowed female respondents who reported property division and who had at least one living child, the division occurred around the time of the spouse's death, compared to 19 percent of widowed male respondents under similar conditions. Limiting our scope to noninstitutionalized widows at risk of dividing property (i.e. those with at least one living child and property to divide or property already divided), we calculated for each demographic and social group the proportion whose property was divided within one year of the spouse's death. The denominator therefore includes widowed respondents who could have, but did not, divide their property. Division of property coincided with the time of spouse's death for almost 20 percent of the respondents $(N=686)$. Coincidences between the time of the spouse's death and the time property was divided were 


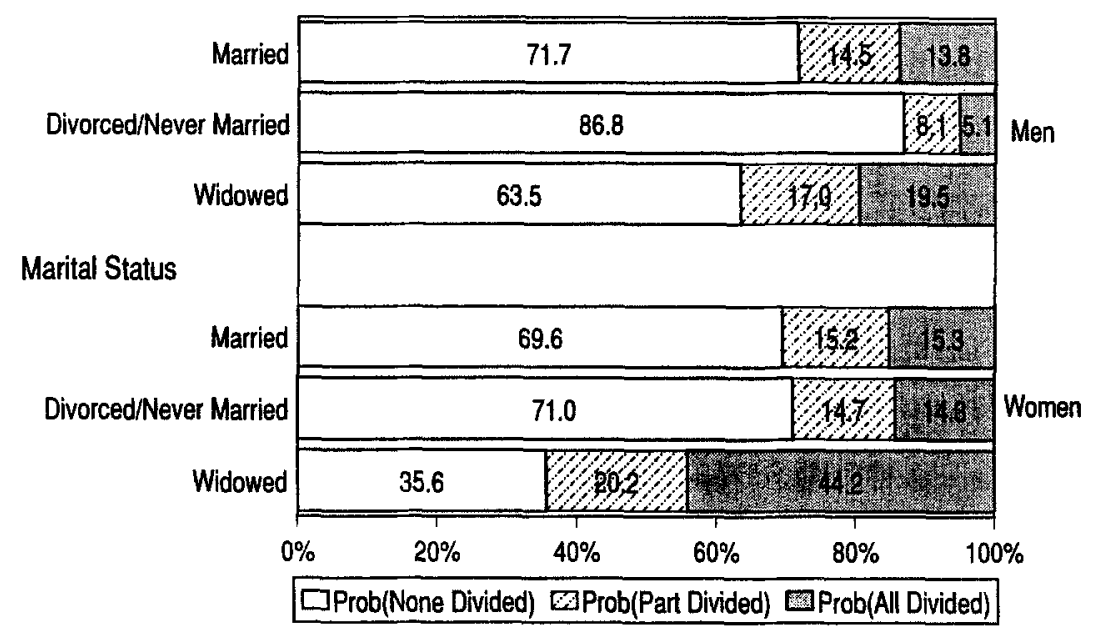

Note: Predicted probabilities are based on Model 3

Fig. 2. Predicted probabilities of property division by marital status and sex Note: Predicted probabilities are based on Model 3

found for more than 20 percent of the female and rural respondents - groups conventionally thought to be less advantaged than their counterparts. Coincidences also occurred more frequently for respondents associated with an illiterate patriarch, for those with two or more living children, and for those with one or more living sons, relative to those with one child or no sons. The latter may reflect the difficulties of consensus-building in larger families about what to do with intestate property. Contrasts by sex, place of birth, ethnicity, and numbers of children showed the greatest differentials in proportions.

\section{CONCLUSION}

Although consideration of tax benefits may prompt the pre-mortem division of property, concern about old age security can provide a strong incentive to discourage division. We readily acknowledge that sibling rivalry and other psychodynamic factors can accelerate or stall the division of family property but our data do not allow us to adequately address these issues. Instead, we have used data from the 1989 Survey of Health and Living Status of the Elderly in Taiwan to explore the demographic and social characteristics associated with property division. The understanding that control of family property is transferred to the children (which appears to be reflected in legal codes, tradition and convention) may become increasingly conditional on the filial behavior of the children if we assume that individuals maximize the likelihood that they will be cared for in old age. If old age security is indeed of concern to the elderly, we should not be surprised to see greater transfer going to the person(s) most likely to provide care. It may even be in the government's interest to lower the 
inheritance tax in order to mitigate incentives for the elderly to transfer their properties prematurely. Ownership of property may provide the elderly with more economic security, and perhaps preserve for them a degree of independence that may prove helpful in negotiations with family members. The fact that our findings showed widowed women to be particularly prone to property division raises the question of whether property division guarantees or threatens old age security.

In our empirical analysis, we have incorporated relatively fixed demographic and social characteristics of the elderly respondents. From both bivariate and multivariate analyses, we found that the likelihood of property division was positively related to age, widowhood, natality in Taiwan, rural residence, and the number of living children, and negatively related to education. After controlling for other characteristics, our results show that widows are more than twice as likely as widowers to have divided all their property. Since the survey data enable us to generalize our findings to the entire population of Taiwan, these results complement findings from anthropological studies on the Chinese family. We certainly recognize the importance of other economic and emotional factors that may predicate the division of property, e.g. income, retirement, attitudes concerning the importance of keeping property, and perceptions about the amount of respect, love, and support received. However, the correct specification of causal linkages between such variables and property division is difficult to establish from one set of cross-sectional data. Just as property division can alter total monthly income, property may not be divided precisely because the division of property affects the outcome (e.g., support, respect). These considerations can be addressed in part by the future availability of longitudinal data, which should allow us to better incorporate the behavior, attitudes, and economic attributes of the elderly in an analysis of property transfers. A more detailed follow-up survey of the respondents who participated in the 1989 Survey is planned for late 1992. When these data become available, we also expect to be better able to separate age and cohort effects.

\section{ACKNOWLEDGEMENTS}

This paper has benefited by comments from Albert Hermalin, John Casterline, Bruce Christenson and three anonymous reviewers. While at the University of Michigan, Rose Maria $\mathrm{Li}$ received support to undertake this research from a U.S. National Institute on Aging (NIA) postdoctoral training grant AG00151 and NIA grant AG07637 for the Comparative Study of the Elderly in Four Asian Countries. Yu Xie was supported by a Young Investigator Award from the National Science Foundation. Direct all correspondence to Rose Li, National Institute on Aging, Behavioral and Social Research Program, 7201 Wisconsin Avenue, Room 2C234, Bethesda, Maryland, 20892, U.S.A. 


\section{NOTES}

1 See also Taiwan Provincial Government Bulletin, Issue no. 65, Winter 1988 which represents the Provincial government's plan concerning senior citizen welfare measures.

2 See also Simmons (1945) and Goldstein, Schuler and Ross (1983) on the connection between control of resources and receipt of care in other societies.

${ }^{3}$ Liu (1959: 69 as cited in Ho 1967: 163) concluded from an extensive analysis of traditional Chinese clan rules that "The principle of giving each son an equal share of inheritance varied somewhat with local custom. In some places, the eldest son received a double share of inheritance either on the ground of his having more grown-up offspring than his younger brothers, or in partial imitation of the ancient feudal rule of primogeniture. Sons of the wife usually got more than the sons of a concubine. But many localities allowed none of these deviations from the principle [of equal inheritance]." It is also of interest to note the distinction between inherited and acquired property. Wolf (1981:349) has pointed out that "with the exception of a small share granted the son of the eldest son, inherited property is always divided equally among brothers. Acquired property, by contrast, is divided according to individual effort."

${ }^{4} \mathrm{Cf}$. Article 1138. In the absence of a will, the spouse's portion of intestate property ranges from an amount at least equal to that of each of the first order heirs (i.e., children or lineal descendants by blood) up to the whole inheritance if there are no other heirs (Article 1144).

5 In linking property transactions with family developments in Taiwan, Susan Greenhalgh (1985: 587) has convincingly argued that a substantial portion of properties are obtained by sons "mostly just before (i.e., within one year of) [their] marriage or the division of the family." Since the data for Greenhalgh's paper, collected during 21 months of research in 1978-80, were based on a nonrepresentative small sample, it is difficult to generalize her findings to the population of Taiwan.

${ }^{6}$ The inheritance tax in the Republic of China is based on the market value of the property at the time of death. After certain legally prescribed deductions, the rates of inheritance tax range from 2 percent on property valued below NT $\$ 300,000$ to 26 percent on property valued more than NT $\$ 7,650,000$ but less than $\mathrm{NT} \$ 10,020,000$ to 60 percent on property valued more than NT $\$ 160,000,000$. Detailed graduated rates of the tax can be found in Article 13 of the Law.

7 Additional incentives for pre-mortem division may exist for a farming family. Effected in 1953, the "Land-to-the-Tiller" Programme made ownership of farm land conditional on the proprietor's working the land and "stipulated that privately owned land in excess of specified amounts per landowner had to be sold to government, which would resell that land to tenants" (Fei, Ranis and Kuo 1979:40). In his report to the ChineseAmerican Joint Commission on Rural Reconstruction, Kirby (1960: 76) noted that "many of the former large households had also split themselves into small families, to avoid the application of this Programme to themselves, and also to escape certain forms of taxation." It seems safe to say that nowadays this policy has little relevance for the general population, as the proportion of the population considered agricultural has declined from 51 percent in 1954 to 20 percent in 1987 (Taiwan Statistical Data Book 1988: 65)

8 This was the case for 30 female respondents.

\section{REFERENCES}

Ahern, E. 1973 The Cult of the Dead in a Chinese Village. Stanford: Stanford University Press.

Andrews, G.R., A.J. Esterman, A.J. Braunack-Mayer, and C.M. Rungie 1986 Aging in the Western Pacific: A Four Country Study. Western Pacific Reports and Studies No. 
1. Manila: World Health Organization Regional Office for the Western Pacific.

Becker, G.S. and N. Tomes 1979 An Equilibrium Theory of the Distribution of Income and Intergenerational Mobility. Journal of Political Economy 87: 1153-1189.

Becker, G.S. 1991 A Treatise on the Family. Enlarged ed. Cambridge: Harvard University Press.

Bernheim, B.D., A. Shleifer, and L.H. Summers 1985 The Strategic Bequest Motive. Journal of Political Economy 93: 1045-1076.

Casterline, J.B., L. Williams, A. Hermalin, M.C. Chang, N. Chayovan, P. Cheung, L. Domingo, J. Knodel, and M.B. Ofstedal 1991 Differences in the Living Arrangements of the Elderly in Four Asian Countries: The Interplay of Constraints and Preferences. Comparative Study of the Elderly Research Reports No. 91-10, Ann Arbor: Population Studies Center, University of Michigan.

Chang, M.C. and M.B. Ofstedal 1991 Changing Attitudes Toward Old Age Support in Taiwan: 1973-1985. Comparative Study of the Elderly in Asia Research Reports No. 91-8, Ann Arbor: Population Studies Center, University of Michigan.

Chen, C. 1985 Dowry and Inheritance. In The Chinese Family and Its Ritual Behavior. H.J. Hsieh and Y.C. Chuang, eds. Pp. 117-127. Taipei: Institute of Ethnology, Academia Sinica Monograph Series B No. 15.

Cohen, M.L. 1976 House United House Divided: The Chinese Family in Taiwan. New York: Columbia University Press.

Cohen, M.L. 1978 Family Partition as Contractual Procedure in Taiwan: A Case Study from South Taiwan. In Chinese Family Law and Social Change. D.C. Buxbaum, ed. Pp. 176-204. Seattle: University of Washington Press.

Fei, J.C.H., G. Ranis, and S.W.Y. Kuo 1979 Growth with Equity: The Taiwan Case. New York: Oxford University Press.

Freedman, M. 1979 Colonial Law and Chinese Society. In The Study of Chinese Society: Essays by Maurice Freedman. G.W. Skinner, ed. Pp. 93-139. Stanford: Stanford University Press.

Freedman, R. 1986 Policy Options After the Demographic Transition: The Case of Taiwan. Population and Development Review 12: 77-100.

Gallin, R. 1986 Mothers-in-Law and Daughters-in-Law: Intergenerational Relations Within the Chinese Family in Taiwan. Joumal of Cross-Cultural Gerontology 1: $31-49$.

Goldstein, M.C., S. Schuler, and J.L. Ross 1983 Social and Economic Forces Affecting Intergenerational Relations in Extended Families in a Third World Country: A Cautionary Tale from South Asia. Journal of Gerontology 38: 716-724.

Greenhalgh, S. 1985 Is Inequality Demographically Induced? The Family Cycle and the Distribution of Income in Taiwan. American Anthropologist 87: 571-594.

Hermalin, A.I., M.B. Ofstedal and L. Chi 1992 Kin Availability of the Elderly in Taiwan: Who Is Available and Where Are They? Comparative Study of the Elderly in Asia Research Reports No. 92-18, Ann Arbor: Population Studies Center, University of Michigan.

Ho, P.T. 1967 The Ladder of Success in Imperial China: Aspects of Social Mobility, 1368-1911. New York: Columbia University Press.

Hsu, F.L.K. 1967 Under the Ancestors' Shadow: Kinship, Personality, and Social Mobility in Village China. New York: Doubleday and Co, Inc.

Kirby, E.S. 1960 Rural Progress in Taiwan. Hong Kong: Hong Kong University.

Li, R.M., and H.S. Lin 1992 Factors in Elderly Transfers of Property to Children in Taiwan. Comparative Study of the Elderly in Asia Research Reports No. 92-17, Ann Arbor: Population Studies Center, University of Michigan.

Liu, H.C. (W.) 1959 The Traditional Chinese Clan Rules. New York: Association for Asian Studies.

Martin, L.G. 1988 The Aging of Asia. Journal of Gerontology 43: S99-\$113.

McKelvey, R.D. and W. Zavoina 1975 A Statistical Model for the Analysis of Ordinal 
Level Dependent Variables. Journal of Mathematical Sociology 4: 103-120.

Moore, J. 1990 Never Say Die. Far Eastern Economic Review 148: 56-57.

Pasternak, B. 1972 Kinship and Community in Two Chinese Villages. Stanford: Stanford University Press.

Pasternak, B. 1983 Guests in the Dragon: Social Demography of a Chinese District 1895-1946. New York: Columbia University Press.

Schurmann, H.F. 1956 Traditional Property Concepts in China. Far Eastern Quarterly 15: 507-516.

Shiga, S. 1978 Family Property and the Law of Inheritance in Traditional China. In Chinese Family Law and Social Change. D.C. Buxbaum, ed. Pp. 109-150. Seattle: University of Washington Press.

Simmons, L.W. 1945 The Role of the Aged in Primitive Society. New Haven: Yale University Press.

Soldo, B.J., and M.S. Hill forthcoming Intergenerational Transfers and the Dynamics of Retirement and Health: Economic, Demographic and Social Perspectives. In G. Maddox, ed. Annual Review of Gerontology and Geriatrics. New York: Springer.

Sun, T.H. 1991 Population Projections and Future Implications: Taiwan, Republic of China. Paper presented at the Workshop on Aging, jointly sponsored by the East-West Population Institute and the Department of Health, the Executive Yuan, Republic of China in Honolulu, Hawaii (3-9 February).

Sung, L.S. 1981 Property and Family Division. In Anthropology of Taiwanese Society. E. Ahern and H. Gates, eds. Pp. 361-378. Stanford: Stanford University Press.

Taiwan Provincial Institute of Family Planning, Population Studies Center and Institute of Gerontology, University of Michigan 1989 Survey of Health and Living Status of the Elderly in Taiwan: Questionnaire and Survey Design. Comparative Study of the Elderly in Four Asian Countries, Research Report No. 1 (December), Population Studies Center, University of Michigan. Taipei: Taiwan Provincial Institute.

Taiwan Statistical Data Book 1988 Republic of China: Council for Economic Planning and Development. Taipei: Council for Economic Planning.

Tang, M.C. 1985 Equal Right and Domestic Structure. In The Chinese Family and Its Ritual Behavior. J.C. Hsieh and Y.C. Chuang, eds. Pp. 61-69. Taipei: Institute of Ethnology, Academia Sinica Monograph Series B No. 15.

Tsuya, N.O. and L.G. Martin 1992 Living Arrangements of Elderly Japanese and Attitudes Toward Inheritance. Journal of Gerontology 47: S45-54.

Watson, R.S. 1985 Inequality Among Brothers: Class and Kinship in South China. New York: Cambridge University Press.

Wolf, A. 1981 Domestic Organization. In Anthropology of Taiwanese Society. E. Ahern and $\mathrm{H}$. Gates. eds. Pp. 341-360. Stanford: Stanford University Press.

Wolf, A. and C.S. Huang 1980 Marriage and Adoption in China, 1845-1945. Stanford: Stanford University Press.

Wolf, M. 1968 The House of Lim: A Study of a Chinese Farm Family. Englewood Cliffs: Prentice Hall.

Xie, Yu 1989 Structural Equation Models for Ordinal Variables. Sociological Methods \& Research 17, no. 4 (May): 325-352.

\section{Rose Maria Li}

Population Studies Center

University of Michigan

1225 S. University Avenue

Ann Arbor, Michigan 40814

U.S.A. 
YuXie

Population Studies Center

University of Michigan

1225 S. University Avenue

Ann Arbor, Michigan 40814

U.S.A.

and

Hui-Sheng Lin

Research and Planning Division

Taiwan Provincial Institute of Family Planning

P.O. Box 1020

Taichung, Taiwan

Republic of China 